\title{
Collaborative Learning Activities through MoE in Engaging EFL Learners and Diminishing their Speaking Anxiety*
}

\author{
Sitti Fatimah \\ Universitas Negeri Padang \\ e-mail: sitti.fatimah@fbs.unp.ac.id
}

\begin{abstract}
Mantle of the Expert (MoE) is an approach integrating drama in learning. A number of studies have proven the approach to be effective in enhancing student's learning experience and vary teacher's teaching strategy. This article is drawn from the results of a multi-case study that implemented MoE in EFL teaching in Indonesia. The study involving three cohorts of Grade 11 Indonesian senior and vocational high school students and three English teachers used multiple data collection methods: classroom observation, questionnaire and interview. While questionnaire was distributed to the student participants, the interview was administered to collect the data from teacher participants. The MoE implementation involved a series of drama activities integrated with the lesson topics. During the activities the student participants were assigned several tasks to be completed in small groups. This required students to collaborate. The findings show that these collaborative learning activities have shown positive major impacts, two of them are students' increased engagement and decreased speaking anxiety.
\end{abstract}

Keywords: EFL learners, collaborative learning, MoE, student engagement, speaking anxiety

How to Cite: Fatimah, S. (2019). Collaborative Learning Activities through MoE in Engaging EFL Learners and Diminishing their Speaking Anxiety. English Language Teaching Educational Journal, 2 (1), 39-49.

\section{INTRODUCTION}

The lack of student engagement and speaking anxiety are two major problems frequently encountered by Indonesian EFL (English as a Foreign Language) learners. Many English teachers are frustrated by these phenomena, but some of the teachers try to cope with them (e.g. Padmadewi, 1998). These teachers usually try to engage the students by creating fun and engaging activities, such as games, role-play, and storytelling. Many teachers believe that these activities are able to improve student's engagement and participation during the teaching and learning processes (Akhyak \& Indramawan, 2013; 2011; Zulkifli \& Fatimah, 2019). However, there are some other teachers who even make a more engaging and challenging endeavour by integrating drama games and activities (Cawthon, Dawson, \& Ihorn, 2011; Chan, 2009). According to them, involving these drama games and activities in teaching and learning processes have proven effective to enhance student's learning experience.

Related to drama games and activities, there has been a concept of drama education; that is the integration of drama in the curriculum or school subjects. In Europe, particularly in the United Kingdom the integration of drama in curriculum has been well implemented since the 1950s. One kind of it that is still implemented not only in UK but also in Australia, Canada and New Zealand is Mantle of the Expert (MoE) that was invented by an English drama educator, Dorothy Heathcote. As it became popular among teachers and educators, a great number of studies and projects have been conducted to investigate its effectiveness and efficiency (see Housum-Steven, 1998; Taylor, 2002 \& 2006; Rouse and Wilde, 2010). 
The research from which this article is drawn was also the implementation of MoE, but to the learners of English where it is used as a foreign language (EFL). Within the concept of MoE the EFL learning activities were emphasized on cross-curricular approach, inquiry-based learning and collaborative learning. However, the discussion in this article only focuses on how collaborative learning activities that were conducted within classroom and imaginary community through small group discussion (work) and role-plays have positive impacts on student engagement and their speaking anxiety. The collaborative learning is selected because this aspect gave significant impacts on teaching and learning processes. Research on the use of MoE in EFL contexts are very few but those using Process Drama are massive (e.g., Yaman Ntelioglou, 2011). To date there is no such research on MoE in Indonesian context, particularly in EFL learning.

\section{The Concept of Mantle of the Expert (MoE) and its Elements}

In 1970s Heathcote introduced the concept of MoE as "an experiential learning and the empowerment of child when s/he assume MoE; and by 1993 the concept of MoE focused on getting children to run a business enterprise" (Hesten, 1994, p. 156). It is this latest concept of MoE that has been applied in teaching the curriculum in many countries and on which this study of MoE implementation is based.

Literally, 'Mantle of the Expert' is divided into: Mantle and Expert. "Mantle means fulfilling a community call and making use of one's potentiality; and Expert means the opportunity to work at knowledge and master the skills" (Heathcote, 2002, p. 2). Thus, Heathcote (as cited in Aitken, 2013) explains that the meaning of Mantle is not literally a piece of cloth generally known to cover body but it refers to the quality. What she means by quality is students' leadership where it contains "behaviour, morality, responsibility, ethics and the spiritual basis of all action" (p. 35). The main goal of MoE is to "provide a centre for all knowledge: it is always experienced by the students in terms of the responsible human being" (Heathcote \& Bolton, 1995, p. 32).

MoE elements can be classified into those that are created in an imaginary community and those that run the imaginary enterprise created in the classroom community. These two groups enable the whole process of $\mathrm{MoE}$ implementation. The first group consists of enterprise (organization), experts, commission and clients. The elements that carry out the enterprise are student-in-role (and out-of-role), teacher-in-role (and out-ofrole), productive tension, and reflection (see Figure 1 below). 


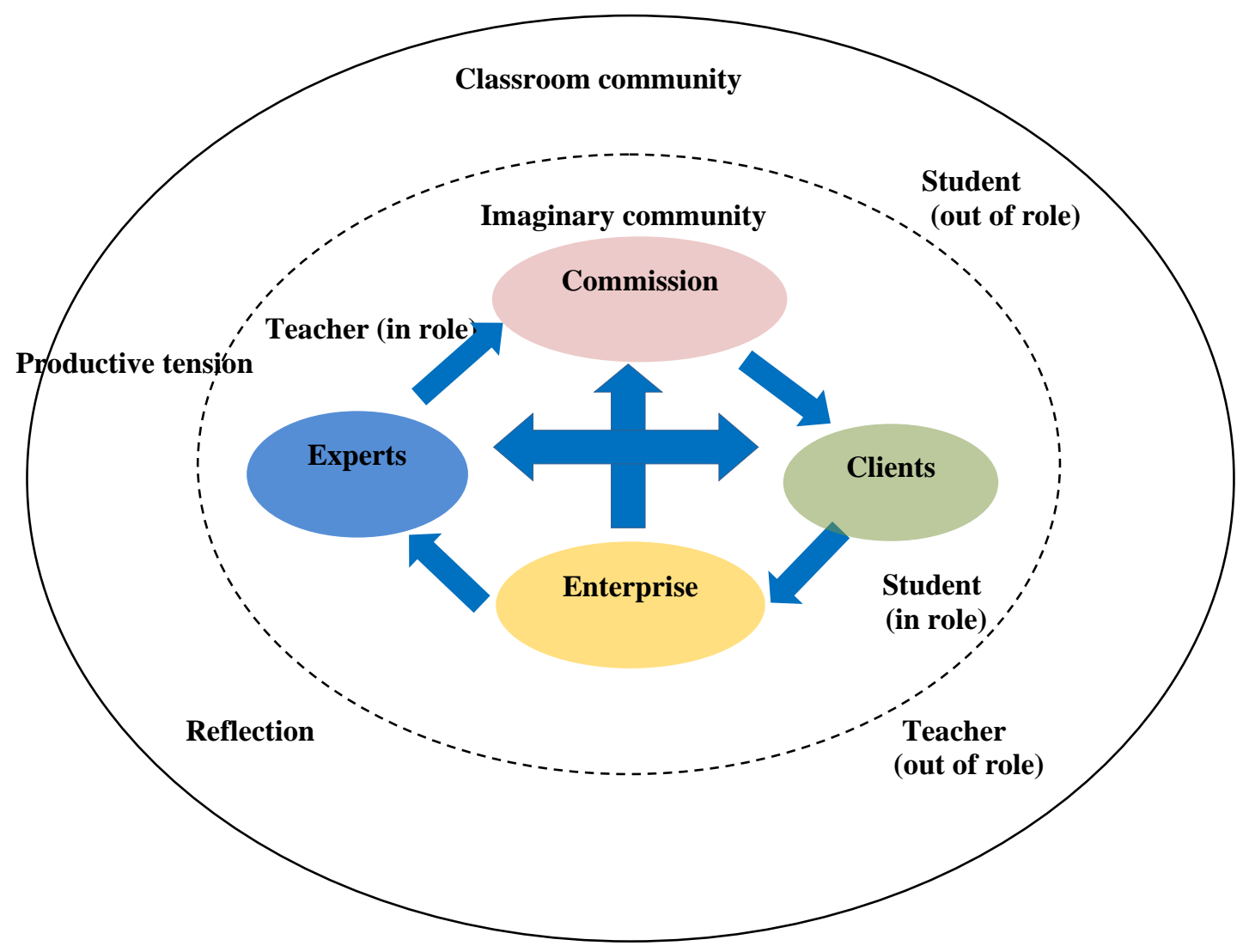

Figure 1. Elements of MoE adapted from from Hesten (1994) and Heathcote (2002)

\section{MoE and Collaborative Learning}

Dillenbourg (1999) has attempted to define collaborative learning as "a situation in which two or more people learn or attempt to learn something together..." (p.1). Two or more people means that in the learning activities the students may be asked to conduct pair or small group work. A great number of studies related to the use of collaborative learning have been conducted whether to hypothesize or to describe the existing phenomena. Most studies have demonstrated the benefits and effectiveness of implementing collaborative learning. For example, Noh and Yusuf (2018) found that collaborative learning style was proven "as one of the most effective learning style for students at a higher education in Aceh".

One of the fundamental principles of $\mathrm{MoE}$ as the drama-based pedagogy is collaborative work. The element of enterprise in MoE strongly suggests that there is collaborative learning approach applied in MoE implementation. Students are assigned tasks in small groups where they become experts of some kinds. The nature of collaboration in drama education is stated explicitly in the following quote:

Drama promotes language development. Its collaborative nature provides opportunities for pupils to develop key skills of communication, negotiation, compromise and self-assertion (Arts Council England, 2003, p. 7).

A classroom action research conducted by Belcastro (2003) confirms the use of collaborative activities during learning with MoE. She explains that: 
Mantle of the Expert mediates inquiry-based education in the way that it creates a practice-oriented classroom. In a practice-oriented classroom learning is focused on activities and practices that aid students in the exploration of how social worlds are constructed and represented. Students and teachers participate as collaborative inquirers, sharing in the decisions of classroom practices, engaging in activities of social worlds, and reflecting on beliefs and values underlying those worlds. (pp. 68-69).

\section{MoE and Foreign Language (speaking) Anxiety}

Foreign language anxiety is a state of anxiety experienced by students in a foreign language classroom context. According to Horwitz et al. (1986), foreign language anxiety is related to students' "self-perception, beliefs, feelings and behaviours..." (p. 128) that they experience during the process of foreign language learning. These mixed perceptions of feelings may result from the teaching method and strategies applied by the teacher, instructor or lecturer. These perceptions and feelings manifest as communication apprehension (Pratolo, 2017), fear of negative evaluation and test anxiety.

The concept of learning underlying the MoE approach is believed to be able to reduce student's anxiety in foreign language learning, particularly in speaking a foreign language. This is because the nature of MoE learning greatly involves collaboration where students work in team in order to complete a task. When working in group is favoured by the students, there is a big opportunity for students to gradually get rid of their anxiety to speak English.

\section{RESEARCH METHOD}

The study used qualitative approach in accordance with the principles of constructivism although some small calculation was taken as the source of data for qualitative analysis. Constructivism is an approach that sees reality as social construction where the role of the researchers is "to understand the multiple social constructions of meaning and knowledge... [that]...will allow them to acquire multiple perspectives" (Robson, 2002, p. 27). Those multiple perspectives are generated by believing in participants' perceptions about the phenomenon being investigated (Creswell, 2009). As constructivism is "the heir of qualitative tradition" (Robson, 2002, p. 26), its major focus is on "things in their natural settings, attempting to make sense of or interpret phenomena in terms of the meanings people bring to them" (Denzin \& Lincoln, 2011, p. 3).

A multiple-case study was adopted because three schools: Udayana, Atlanta and Dharmawangsa (these names are pseudonyms) were involved to obtain the data. Three English teachers (Umaira, Rossa and Diana; also pseudonyms) and their classes (89 students in total) became the participants of the study. These students were sitting at Grade 11 and were on their second semester when they were invited as the participants.

The data were collected through 1) classroom observations, 2) semi-structured interview with teacher participants and 3) questionnaire distributed to student participants. However, the data presented in this article are only obtained from students' responses of the questionnaire that consisted of closed and open-ended questions. While the data resulted from closed-ended questions were analysed with percentage, those from the open-ended were analyzed using Qualitative Content Analysis approach. Data coding applied the qualitative content analysis procedures suggested by both Mayring (2000) and Hsieh and Shannon (2005): deductive category application (directed content analysis) and inductive category development (conventional or classical content analysis). The process of data coding or of naming the categories in deductive category application is carried out. 


\section{FINDINGS AND DISCUSSION}

The data presented in this section are derived from students' responses to an openended question asking students about their perception of collaborative work during MoE activities and teachers' perceptions of collaborative learning. This open-ended question also allowed the students to provide more than one answer and the teachers (Umaira, Rosa and Diana) to give in-depth explanation.

\section{Collaborative Learning and Student Engagement}

According to Kao and O’Neill (1998), while Process Drama usually begins with a large group or whole class activity, to sustain Process Drama, teachers usually assign students to work in small groups or pairs. This was certainly the case across all three cases. Throughout the MoE implementation, combinations of students completed tasks and conducted role-plays within these same groupings. Across the three cases, the majority of students were positive to the question about their perception of collaborative work. Most students enjoyed doing activities in groups and outlined various benefits of collaborative work to their learning as mainly voiced by the teacher participants during the semistructured interview which is described below.

\section{Gradual increase in student engagement}

Although Atlanta students' major reasons for their enjoyment of group work were different from the other two groups of students, in responding to a question about the activity that most encouraged them to speak English, almost half of them chose the activity of group work. Their responses are exemplified by three students below:

I think the collaboration greatly helped me develop my learning.

I think it's so beneficial for me. The activities add my knowledge.

Collaborative work in MoE activities is the best.

By implication, Atlanta students enjoyed group work because it gave them new learning experiences and new knowledge as discussed above, but they also believed that it gave them the opportunity speak English. Atlanta students' explanations suggest that although they had done role-play activities in previous English language learning, these were different from the role-plays they performed during MoE. In their previous role-plays they were required to memorize scripted dialogues and practice them. During the group work activities of MoE, they had no script to memorize as the dialogue was spontaneous and their teacher, Rossa, took on a role together with them.

The responses from Rossa about student engagement was similar to the students' although at the first semi-structured interview she complained that some students were not really engaged with the lesson. However, by her second semi-structured interview (after implementing the first four MoE lessons), Rossa had quite a different sense of the state of student engagement:

They have improvement in participation and motivation after third and fourth meeting. We can see from the class that they are interested in learning English now, for example, in the first and second meeting, half of the students are not interested in the classroom. Or I can say that only two or three students that are motivated in learning, only two or three students in one group. But after the third and fourth meeting, there are more students that are interested in learning. It can be five until six students, so it means that there is good improvement from the 
classroom...They are interested in learning through drama (Rossa, SemiStructured Interview 2).

Meanwhile, most of the Udayana students who perceived the benefit of collaborative work valued it as a technique that increased their interest in English learning. Some others reported that group work increased their participation in learning and improved their understanding of the lessons and their English speaking ability as quoted below:

I think the collaboration was very interesting for learning process.

It can help students to master all learning materials well.

I think it's very interesting because we can improve our speaking ability and improve our confidence too.

I think it's good because all students can participate in the designing activities well and none of them being idle, at least they did it diligently

The students' views about their increased participation and improved understanding were in line with Umaira's observations about the benefits of small group activities (both in-role and out of role). She preferred to assign students to work collaboratively because she understood that peer support can be just as important and efficient as teacher support to engage students in their learning. She observed that having a small number of students in each group enabled each member to participate in the discussion and to exchange ideas. Further, Umaira witnessed that working in groups also helped the students who had less understanding of the lesson content "... so because of their friends' assistance they could understand [the lesson/activities]" (Umaira, Semi-Structured Interview 3).

From her observations, Umaira identified three benefits of students doing activities in small group. First, each student was enabled to participate in discussion to share and exchange ideas. Second, the students were enabled to prepare their roles for public performance role-play: "I think most of them have confidence... If I ask them to present or I ask them to perform, most of them can do that (Umaira, Semi-Structured Interview 1). Third, through discussion with peers, the students had opportunities to deepen their understanding about tasks and lesson content.

In the case of Dharmawangsa, Diana noted significant changes in students' willingness to speak English after two lessons of learning through MoE although she didn't seem satisfied with the student's progress. However, Dharmawangsa students valued collaborative work in small group discussion because, in their view, it improved their English speaking ability, and increased their English speaking confidence, their understanding of the lessons and their mastery of vocabulary as the following quotes show.

It is easier for me (to understand English) and I don't feel complicated

I think it is very good because it makes me understand English more

It is exciting and useful to understand English vocabulary more

Very effective, with these activities in MoE approach we can get close to each other

The importance of group work has been discussed in the research literature and investigated through several studies, both as a dimension of Process Drama and as a technique in teaching and learning processes within ESL/EFL instruction. Liu (2002) presents three functions of drama in a language classroom. One of them is the cognitive function that provides opportunities for to work collaboratively and creatively in order to develop their language skills. Liu's collaborative and creative learning outcomes of Process 
Drama were seen in most activities of $\mathrm{MoE}$ in all cases. The students in this study conducted many small group activities, either to complete writing tasks or to prepare for public performance role-plays. While improvements to students' English language skills were not assessed as a dimension of this study, creative engagement with tasks was, indeed, an observable outcome of MoE implementation.

A study conducted by SæbØ (2011), investigating the relationship between individual and collective aspects of learning, found that 'collective learning' in small groups during Process Drama contributed significantly to promoting individual student learning. She concluded that "individual and collective aspects of the learning process are reciprocally dependent on each other, but it is the quality of the collective learning process that decides the quality of the individual learning process in drama" (p. 26). This finding suggests that collaborative learning has the potential to improve individual learning. Although the current study did not specifically investigate the influence of collaboration on the quality of student learning, high levels of student engagement during group tasks across all three cases indicate the positive contribution of group work to student learning.

A number of other studies focusing on the implementation of small group work and collaborative learning showed different results. In their experimental study, van Blankenstein, Dolmans, van der Vleuten, and Schmidt (2011) investigated the effects of giving explanations and listening during small group discussion on students' long term memories. The findings showed that the activities affected positively their recall of related subject-mattered after discussions in small groups. On the other hand, a case study by Osman, Duffy, Chang, and Lee (2011) did not offer any particular positive impacts of small group discussion on student learning.

The impact of group work on ESL (English as a Second Language) or EFL (English as a Foreign Language) learning has been investigated through a number of studies conducted in the last three decades and these confirm the findings in this study. For example, Pica and Doughty (1985) found that "group work: 1) provided students with more opportunities to practice using the target language, and 2) to engage in direct interaction" (p. 247). The first effect of group work found in Pica and Doughty's study aligned with Atlanta students' perceptions of the benefits of being in-role during group work, as previously discussed. Umaira similarly perceived the advantage of group work to encourage Udayana students to speak English.

In addition to Pica and Doughty's findings about the advantages of group work in ESL or EFL learning, Long and Porter (1985) identified four more benefits of group work to students' language acquisition. These are that it: 1) improves the quality of student talk, 2) helps individualize instruction, 3) promotes a positive affective climate, and 4) motivates learners (pp. 208-212). While the first benefit of group work identified by Long and Porter was not investigated through this study, the second finding can be seen in this study among students' MoE activities through small group work. Each group of students in Udayana SHS and Atlanta SHS came up with different $L P K$ proposals although the task set was similar for all. This was because they responded differently to the task. It allowed the options for "small groups of students [to] work on different sets of materials suited to their needs... group work, then, is a first step toward individualization of instruction" (Long \& Porter, 1985, pp. 210-211). Long and Porter's third point that group work positively affects the learning climate is evident in this study, particularly in case two where Atlanta students were encouraged to speak English in small group role-plays without inhibition. The effect on motivation was evident across the cases.

Richards (2006) suggested that in group work the students "produce a greater amount of language than they would use in teacher-fronted activities [classroom activities or discussion]" (p. 20). Meanwhile, Long and Porter conclude that "group work motivates 
learners" (p. 212). Their argument is in accordance with Richards' (2006) who also believes that through group work activities students' motivation tends to increase. In line with the above benefits of group work, Harmer (2007) also identifies some advantages of grouping students within English language teaching and learning. According to him, group work significantly increases speaking opportunities for students, and creates greater possibility for students to voice different opinions. Thus, various contributions of ideas are enabled, and cooperation and negotiation skills are enhanced. Findings from these studies are apparently in line with student learning experiences in this study. As discussed previously, group work increased Dharmawangsa students' willingness to speak English and provided a number of benefits to Udayana students.

A study by Sutiah (2011) about implementing CLT during group work with Indonesian primary students likewise reported positive effects of group work on students' speaking confidence. She highlighted that the students became more confident to give oral presentations within group presentations, and in contrast, became anxious in individual presentations due to concerns about their lack of proper pronunciation. This finding suggests that group activity can increase students' speaking confidence and, at the same time, reduce their language anxiety.

To conclude, collaborative learning undertaken within the frame of a real or an imaginary context was experienced by the students across the cases and was a significant factor in their positive engagement with the English language learning process. Their heightened engagement created the possibility for students improved learning experiences that may lead to improvements in their language learning outcomes.

\section{Collaborative Learning as a Mediator to Reduce Speaking Anxiety}

Despite heightened student engagement while in-role during the enactment of MoE, the findings did indicate that some students felt anxious about taking on a role. The number of students who felt anxious in being in-role was especially significant, with $56 \%$ of Atlanta students choosing 'nervous' (in the instrument of questionnaire) as one of the descriptors of their feelings about taking on a role. This nervousness may be understood as a form of 'communication apprehension,' which Horwitz, Horwitz, and Cope (1986) explain is a "a type of shyness characterized by the fear of or anxiety of communicating with people" (p. 127) during foreign language instruction.

Horwitz et al. (1986) suggest that to reduce students' anxiety the teacher should "make the learning context less stressful" (p. 131). One way of achieving this during MoE implementation is by engaging students in small-group role-plays, including the teacher-inrole, as opposed to public performance role-plays. MoE implementation to Atlanta students resulted in findings showing that despite their nervousness, all Atlanta students enjoyed having their teacher-in-role during small group role plays; $62 \%$ of responses indicated willingness to speak English during small group role-plays; and $69 \%$ of responses described enjoyment in small group role-plays. Taken together, these findings suggest the benefits of using small group role-plays to combat student apprehension. This supports the findings revealed by Effiong (2015) stating that peer collaboration and working in small groups reduce feelings of anxiety amongst EFL learners' pronunciation. This finding suggests that group activity can increase students' speaking confidence and, at the same time, reduce their language anxiety.

The kind of anxiety felt by Atlanta students is, according to existing studies, commonly experienced by students learning a foreign language, and must be minimized in order to achieve their maximum learning outcomes. The collaborative and small group speaking activities of MoE seemed to be a good approach for reducing student anxiety about learning and speaking English and may be seen as a stepping-stone to more public 
presentation and performance tasks. Collaboration proved to be a powerful learning platform and it reduced students' English speaking anxiety.

\section{CONCLUSION}

The findings of the study indicate one major outcome of MoE implementation, that is collaborative learning activities conducted through both classroom and imaginary context resulted in positive effects. The collaboration between learners that occurred in small groups benefited the students because it: 1) improved English speaking ability and confidence, 2) increased student interest and participation in learning, 3) increased understanding of their lessons, 4) provided students with new knowledge and learning experiences, 5) provided students with more opportunities to practice the target language being learned, and 6) engaged students in interaction. The findings related to student engagement in small group role-play and students' increased confidence to speak English suggest that spoken interaction in small group had reduced students' anxiety to speak English. This occurred because the students found that learning environment was less stressful.

\section{REFERENCES}

Akhyak, \& Indramawan, A. (2013). Improving the students' English speaking competence through storytelling. International Journal of Language and Literature, 1(2), 18-24. Retrieved from www.aripd.org/ijll

Aitken, V. (2013). Dorothy Heathcote's mantle of the expert approach to teaching and learning: A brief introduction. In D. Fraser, V. Aitken, \& B. Whyte (Eds.), Connecting Curriculum, Linking Learning (pp. 34-56). Wellington, New Zealand: NZCER Press.

Arts Council England. (2003). Drama in schools. 2nd. Retrieved from http://www.artscouncil.org.uk/media/uploads/documents/publications/725.pdf

Belcastro, D. A. (2003). An action research study on using drama for learning: Implementing Dorothy Heathcote's Mantle of the Expert approach to education. (Master's Thesis), The Ohio State University. Retrieved from http://rave.ohiolink.edu/etdc/view?acc_num=osu1393341342

Cawthon, S. W., Dawson, K., \& Ihorn, S. (2011). Activating student engagement through Drama-Based Instruction. Journal for Learning Through the Arts, 7(1), 31. Retrieved from http://search.proquest.com/docview/1312421295?accountid=12528

Chan, Y.-1. P. (2009). In their own words: how do students relate drama pedagogy to their learning in curriculum subjects? Research in Drama Education: The Journal of Applied Theatre and Performance, 14(2), 191-209. doi:10.1080/13569780902868770

Creswell, J. W. (2009). Research design: Qualitative, quantitative, and mixed methods approaches (3rd ed.). Thousand Oaks: Sage Publication, Inc.

Denzin, N. K., \& Lincoln, Y. S. (Eds.). (2011). Qualitative research (4th ed.). Los Angeles: Sage Publications, Inc. 
Dillenbourg, P. (1999) What do you mean by collaborative learning? In P. Dillenbourg (Ed) Collaborative-learning: Cognitive and Computational Approaches (pp.1-19). Oxford: Elsevier

Effiong, O. (2015). Getting them speaking: Classroom social factors and foreign language anxiety. TESOL Journal, n/a-n/a. doi:10.1002/tesj.194

Harmer, J. (2007). The practice of English language teaching (4 ed.). London: Pearson Education ESL.

Heathcote, D. (2002). Contexts for active learning - Four models to forge links between schooling and society. The Journal for Drama in Education, 19 (1), 1-14. Retrieved from http://pers-www.wlv.ac.uk/ in5127/natdtest/journal\%20backcopies.html

Heathcote, D., \& Bolton, G. (1995). Drama for learning: Dorothy Heathcote's Mantle of the Expert approach to education (O. N. Cecily Ed.). Portsmouth, NH: Heinemann.

Hesten, S. (1994). The Dorothy Heathcote archive. (Ph. D. Thesis). Retrieved from http://www.mantleoftheexpert.com/community/research/

Horwitz, E. K., Horwitz, M. B., \& Cope, J. (1986). Foreign language classroom anxiety. The Modern Language Journal, 70 (2), 125-132. doi:10.1111/j.15404781.1986.tb05256.x

Housum-Stevens, J. B. (1998). Performance possibilities: Curating a museum. Voices From the Middle, 6 (2), 19-26. Retrieved from

http://search.proquest.com.ezproxy.lib.monash.edu.au/eric/docview/213929912/fullte xtPDF/135D6CCF0F8199231AA/2?accountid=12528

Hsieh, H.-F., \& Shannon, S. E. (2005). Three Approaches to Qualitative Content Analysis. Qualitative Health Research, 15 (9), 1277-1288. doi:10.1177/1049732305276687

Liu, J. (2002). Process drama in second and foreign language classrooms. in G. Brauer (Ed.), Body and language: Intercultural learning through drama (pp. 51-70). Connecticut, London: Ablex Publishing.

Long, M. H., \& Porter, P. A. (1985). Group work, interlanguage talk, and second language acquisition. TESOL Quarterly, 19(2), 207-228. doi:10.2307/3586827

Mayring, P. (2000). Qualitative content analysis. Forum: Qualitative Social Research, 1(2), 159-176.

Noh, M. A. C., Yusuf, S. A. M. (2018). Collaborative learning technique within higher learning education students. Creative Education, Vol. 9, 2367-2375.

Osman, G., Duffy, T., Chang, J.-y., \& Lee, J. (2011). Learning through collaboration: student perspectives. Asia Pacific Education Review, 12 (4), 547-558. doi:10.1007/s12564-011-9156-y 
Padmadewi, N. N. (1998). Students' anxiety in speaking class and ways of minimizing it. Jurnal Ilmu Pendidikan, 5 (Supplementary Edition), 60-67.

Pica, T., \& Doughty, C. (1985). The role of group work in classroom second language acquisition. Studies in Second Language Acquisition, 7 (02), 233-248. doi: doi:10.1017/S0272263100005398

Pratolo, B. W. (2017). Exploring Indonesian learners' beliefs about language learning strategies through reflection. figshare. Doctoral Thesis. Monash University Australia. https://monash.figshare.com/articles/Exploring Indonesian learners beliefs about la nguage_learning_strategies_through_reflection/4711927. https://doi.org/10.4225/03/58b7763874bf3

Richards, J. C. (2006). Communicative language teaching today. New York: Cambrige University Press.

Robson, C. (2002). Real world research (2nd ed.). Oxford: Blackwell Publishing Ltd.

Sutiah. (2011). The implementation of Communicative Language Teaching (CLT) within group-work in an English as foreign language (EFL) elementary classroom in Indonesia. International Journal of Arts and Sciences, 4 (24), 205-258.

SæbØ, A. B. (2011). The relationship between the individual and the collective learning process in drama. In S. Schonmann (Ed.), Key concepts in Theatre/Drama Education (pp. 23-27). Rotterdam: Sense Publishers.

Van Blankenstein, F., Dolmans, D. J. M., Van der Vleuten, C. M., \& Schmidt, H. (2011). Which cognitive processes support learning during small-group discussion? The role of providing explanations and listening to others. Instructional Science, 39 (2), 189204. doi:10.1007/s11251-009-9124-7

Yaman Ntelioglou, B. (2011). Drama and English language learners. in S. Schonmann (Ed.), Key Concepts in Theatre/Drama Education (pp. 183-188). Rotterdam: Sense Publishers.

Zulkifli, A. A. \& Fatimah. S. (2018). Using Werewolf game to teach speaking to senior high school students. Journal of English Language Teaching, 8 (1), 61-70. 